\title{
재가노인 낙상환경위험 평가도구 개발 Development of the Home Fall Prevention Checklist for Community-dwelling Older Adults
}

\author{
박은옥, 장인순 ${ }^{* *}$ \\ 제주대학교*, 한국성서대학교**
}

Eunok Park(eopark@jejunu.ac.kr)*, Insun Jang(agape90@bible.ac.kr)**

\section{요약}

본 연구는 재가노인의 낙상환경위험평가 도구를 개발하고, 신뢰도와 타당도를 검정하는 방법론적 연구이 다. 예비문항은 20 인의 관련 전문가에 의한 $\mathrm{CVI}$ (내용타당도 지수)를 사용한 내용타당도 검정을 실시하여 최종 52 문항을 선정하였다. 최종도구의 타당도 및 신뢰도 검정을 위해 65 세 이상 재가노인 299명에게 자료 수집을 실시하여 분석하였다. 그 결과 조사자간 신뢰도는 1 개 문항을 제외한 51 개 문항에서 모두 kappa 값이 0.80 이상으로 나타나 신뢰도가 인정되었고, 재조사방법을 통하여 나타난 일치율은 45 개 문항에서 모 두 $80.0 \%$ 이상으로 나타났다. 구성타당도도 낙상군과 비낙상군간에 낙상환경위험평가 점수가 통계적으로 유의한 차이를 나타내 입증되었다 $(\mathrm{t}=3.50, \mathrm{p}=.001)$. 본 도구는 타당도와 신뢰도가 검증되었고, 낙상예방을 위한 더 안전한 환경의 개발과 관련된 추후연구에 기여할 것이다.

중심어 : | 노인 | 낙상환경위험 | 도구 |

\section{Abstract}

The purpose of the study was to develop the home fall prevention checklist for community-dwelling older adults. And the validity and reliability of the checklist were tested. The preliminary questions were developed through content validity by twenty experts using the CVI(Content Validity Index). Following the establishment of content validity, 52 items of the checklist were developed. Responses of 299 community-dwelling older adults were analyzed to further establish both reliability and validity of the checklist. Reliability using cohen's kappa coefficient and test-retest reliability(rate of concordance(\%)), and construct validity using known-group comparison technique were tested. 51 items were over 0.80 in the cohen's kappa coefficient of the checklist, 45 items were over $80.0 \%$ in test-retest reliability. Construct validity was established by known-group comparison(t=3.50, $\mathrm{p}=.001$ ). Validity and reliability of the checklist were confirmed. This checklist will help further studies to develop more safe environment to prevent falls.

- keyword : | Aged | Accidental Falls | Checklist |

\footnotetext{
* 본 논문은 2012년 제주특별자치도의 지원을 받아 수행한 [노인의 낙상위험평가도구 개발 및 실태조사] 과제에서 수집된 자료를 이용하였으며, 해당 보고서에서 일부 내용을 수정하여 사용하였습니다. 또한, 본 연구에서 사용된 자료의 일부는 [재가 노인의 낙상 경험률과 관련요인] 논문에서도 활용되었음을 밝힙니다.
}

접수번호 : \#130222-001

접수일자 : 2013년 02월 22일
심사완료일 : 2013년 04월 04일

교신저자 : 장인순, e-mail : agape90@korea.com 


\section{I. 서론}

\section{1. 연구의 필요성}

낙상은 65 세 이상 노인에게 흔한 건강문제 중 하나이 다. 노인의 낙상은 골절, 뇌손상, 사회심리학적 기능장 애 등 각종 심각한 손상을 초래하며, 입원 등으로 인한 기능제한, 심한 경우 사망에 이르게 하는 중요한 보건 문제 중 하나이다[1].

낙상은 갑작스러운 마비나 발작 외압에 의해 넘어지 는 것을 제외하고 자신이 의도하지 않은 자세 변화로 인해 몸이 더 낮은 위치로 넘어지는 사건으로[2] 일반 적으로는 균형을 잃고 넘어져 발바닥 이외의 신체 일부 가 지면 또는 바닥에 닿는 상황을 의미한다.

세계적으로 볼 때, 65 세 이상의 노인들 가운데 약 28-35\%가 매년 낙상을 경험하며 70세 이상에서는 $32-42 \%$ 로 올라간다. 낙상의 빈도는 연령이 높아지고, 허약한 수준이 올라감에 따라 증가한다. 매년 장기요양 소에서 요양 중인 노인들의 30-50\%는 넘어지는 것으로 보고되고 있고, 이 가운데 $40 \%$ 는 반복적으로 넘어지는 것으로 보고되고 있다[3]. 국내의 2011년도 노인실태조 사에 따르면, 노인의 $21.0 \%$ 가 지난 1 년간 낙상을 경험 하는 것으로 보고되었고, 이 중 낙상으로 인해 병원치 료를 받은 경우는 $72.4 \%$ 이고, 낙상으로 인한 후유증을 않고 있는 경우는 $47.4 \%$ 이었다[4]. 이렇듯 낙상은 직접 적인 신체적 손상으로 이환율, 사망, 부동, 입원, 응급실 방문, 장기요양시설의 조기입소 등을 초래할 뿐만 아니 라 낙상에 대한 두려움, 자신감 상실, 의존, 보행의 제 한, 자율성의 상실, 혼란한 상태, 우울증 등으로 삶의 질 을 저하하는 요인이 되기도 한다[2][3][5][6].

Tinetti와 Kumar[7]는 체계적 문헌고찰로 지역사회 에 거주하는 노인의 낙상위험요인으로 이전 낙상경험, 균형감 저하, 근력 약화, 시력문제, 4 개 이상 또는 정신 계 약물복용, 보행 어려움, 우울, 현기증 또는 체위성 저 혈압, 기능적 제한, 일상생활 제한, 80세 이상, 여성, 저 체중, 요실금, 인지장애, 관절염, 당뇨병, 통증을 제시하 였고, $\mathrm{WHO}[3]$ 은 지역사회 노인의 낙상에 관련된 위험 요인으로 생물학적 위험요인과 행동적 위험요인, 환경 적 위험요인, 사회경제적 위험요인으로 구분하여 제시
하였다. 낙상과 관련하여 생물학적, 행동적 위험요인 뿐 만 아니라 최근에는 사회경제적 요인을 고려하여 저소 득층을 대상으로 연구들이 이루어지기도 했다[1][8]. 노 인의 낙상에는 환경적 위험요인이 기여하는 바가 크다. 2011년도 노인실태조사에 의하면, 낙상을 경험한 장소 는 도로 또는 공원 등 실외가 $56.0 \%$ 로 가장 많았고, 계 단, 화장실/욕실, 방, 거실/마루, 부억 등 집안의 장소가 $35.9 \%$ 정도로 나타났고, 낙상 이유로 바닥이 미끄러워 서가 $29.8 \%$, 문턱에 걸려서가 $8.2 \%$, 사람이나 사물에 부딪혀서가 $5.7 \%$, 경사가 급해서가 $3.4 \%$, 조명이 어두 워서 $0.8 \%$ 등 환경적인 요인이 $47.9 \%$ 로 보고되었다[4]. 이와 같이 낙상은 환경을 개선함으로써 30-50\%까지 사 고를 줄일 수 있는 예방 가능한 건강문제일 수 있다[9]. 환경적 위험요인들은 개인의 신체적 조건들, 주택 내 위험들, 공공환경의 위험한 양상 등을 포함한 주위의 환경과의 상호작용들을 포함한다. 이 위험요인 그 자체 만으로는 낙상의 원인이라고 말할 수는 없으나 이 요인 들이 다른 요인들과 상호작용하거나 사람이 위험한 환 경에 노출되는 경우에 위험요인이 된다. 환경적 위험요 인에는 좁은 계단, 미끄러운 계단의 표면, 고정되어 있 지 않은 깔개, 그리고 불충분한 조명 등이 포함된다. 또 한 실내의 턱이나 계단, 미끄러지기 쉬운 바닥, 신발, 전 기코드, 현관의 턱이나 계단 등도 위험요인이 된다[3]. 또한 낙상 예방을 위한 환경적 중재는 단순한 물리적 환경의 조절보다는 각 개인의 특이적인 상황과 환경간 의 적합성을 고려해야 하며, 각 개인의 기능적 제한 상 태에 근거한 환경 개조에 중점을 두어 개인과 환경의 상호작용을 최대화할 수 있는 중재방법을 모색하고 적 용해야 함을 지적하였다[1][8][10].

American Geriatrics Society and British Geriatrics Society에 의한 노인 낙상예방 가이드라인[6]에서도 환 경 위해 요인을 발견하고 개선하는 것은 여러 성공적인 낙상 예방 프로그램에서 권유되고 있으며, 이전 낙상 경험이 있거나 낙상의 위험이 있는 노인을 대상으로 집 안 환경을 평가, 추적 관찰, 개선하는 것이 필요하다고 하였다. 또한 프로그램 내용으로 전문가에 의한 집안 위험 요인 평가, 위험 요인 완화 혹은 제거, 안전 장치 도입(계단 난간 설치, 욕실에 가로 막대 설치), 조명 개 
선 등을 포함하였다. 지역사회 거주 노인에서 집안 환 경평가와 중재요법은 단독 요법으로는 낙상 예방의 효 과가 연구마다 일치하지 않았으나, 다요인적 중재요법 의 한 부분으로서는 그 효과는 분명하다고 평가하였다. 지역사회 거주 허약노인을 대상으로 진단적 가정방문, 가정 위험요인 사정, 가능한 변화에 대한 조언, 가정환 경 변화에 필요한 기구 제공, 보조기구 사용에 대한 훈 련 등을 포함한 중재 후 무작위 통제 실험연구에서 낙 상경험에 통계적 유의한 차이를 보이는 결과도 있었다 [11]. 이렇듯 낙상과 관련된 환경위험 사정은 낙상과 관 련된 위험요인을 발견하고 개선하는데 도움이 됨에도 불구하고, 우리나라 실정에 맞는 낙상환경위험요인을 평가 도구는 거의 없는 상태이다. Lim, June과 Yoon[5] 은 가정환경위험 평가를 위해 조명, 마루바닥과 장판, 욕실과 화장실, 부억환경, 난방과 냉방, 개인안전, 집밖 출입, 방출입의 8개 항목을 선택하여 평가하였다. 이와 같이 연구자의 판단에 의해 필요한 가정환경위험요인을 선택하여 평가하는 방법도 있지만 많은 선행연구에서는 외국에서 개발된 도구를 사용하거나 그 내용 중 일부를 수정하여 사용하고 있는 상황이었다. 주로 많이 사용된 국외의 낙상환경위험 평가도구로는 Tideiksaar[12]가 개발한 Home Environmental Checklist[1][13][14], The Merck Manual of Geriatrics[15][16]에서 낙상위험에 대 한 가정용 점검표[17], Josephson, Fabacher와 Rubenstein[18]이 개발한 Checklist for home fall hazard 내용[8][19][20] 등이 있다.

낙상과 관련된 생물학적, 행동적, 환경적, 사회경제적 위험요인들이 복합적으로 작용하여 발생하므로 이들 요인을 모두 고려하여 낙상위험요인을 파악하는 것이 중요하다. 그러나 환경적 위험요인 파악 시 국외에서 개발된 도구를 주로 사용하고 있으므로 우리나라의 좌 식생활 등의 주거 특성이 정확히 반영되지 못했거나 일 부 환경에 대한 선택적 문항으로 평가했던 한계가 있었 기에 우리나라 가정환경의 구조적, 기능적 특성을 고려 한 재가 노인의 낙상환경위험요인을 평가하기 위한 도 구 개발이 필요한 실정이다.

\section{2. 연구 목적}

본 연구에서는 우리나라 재가 노인의 거주 환경에 적 합한 낙상환경위험요인을 평가하기 위한 도구를 개발 함으로써, 효율적인 낙상예방관리를 위한 기초자료를 마련하고자 한다.

\section{II. 연구 방법}

\section{1. 연구 설계}

본 연구는 65 세 이상의 재가노인의 낙상환경위험평 가 도구를 개발하고, 신뢰도와 타당도를 검정하는 방법 론적 연구이다.
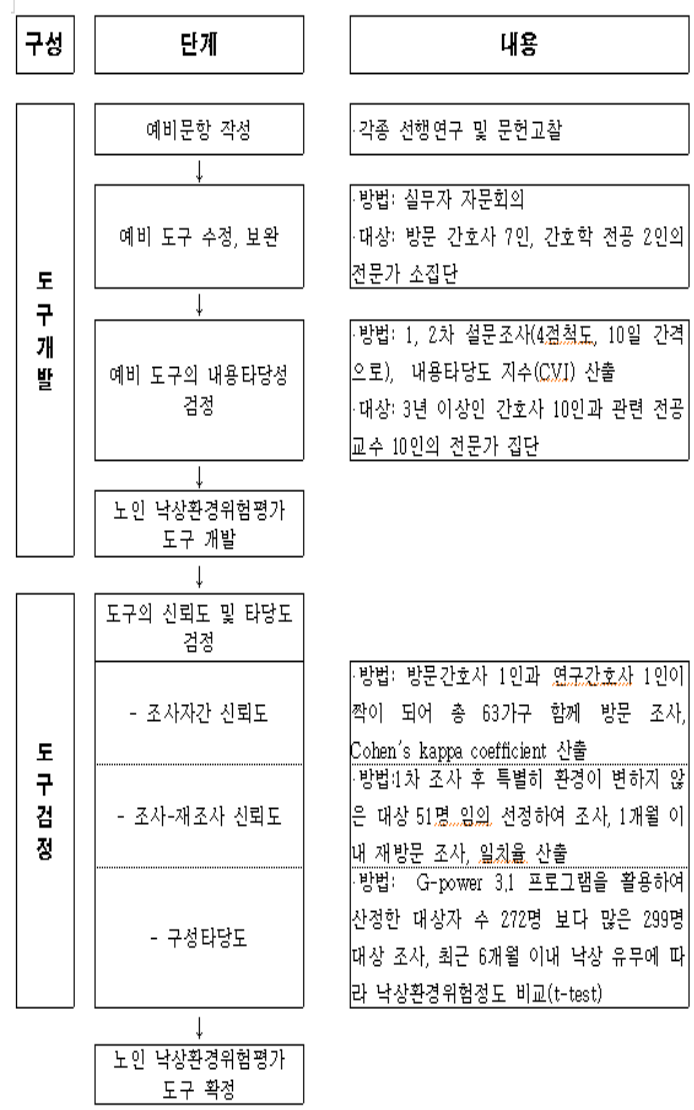

\section{각종 선행연구 및 문헌고찰}

방법: 실무자 자문회의
대상: 방문 간호사 7 인, 간호학 전공 2 인의 전문가 소집단

방법: 1, 2차 설문조사(4점척도, 10 일 간격 으로), 내용타당도 지수(CVI) 산출 대상: 3 년 이상인 간호사 10 인과 관련 전공 교수 10 인의 전문가 집단

방법: 방문간호사 1 인과 였고간호산 1 인이 짝이 되어 촣 63 가구 함께 방문 조사, Cohen's kappa coefficient 산출 방법:1차 조사 후 특별히 환경이 변하지 않 은 대상 51 명 임의 선정하여 조사, 1 개월 이 내 재방문 조사, 일치율 산출

방법: G-power 3.1 프로그램을 활용하여 산정한 대상자 수 272 명 보다 많은 299 명 대상 조사, 최근 6 개월 이내 낙삼 유무에 따 라 낙상환경위험정도 비교(t-test)

그림 1. 연구진행 절차 


\section{2. 도구개발과정}

\section{1 예비문항 구성단계}

\section{1 .1 예비문항 선정}

낙상환경위험요인 평가도구 개발을 위하여 국내외에 서 개발된 낙상환경위험평가 도구와 관련된 문헌을 검 토하여[1][5][8][12-22] 연구팀에서 집주변 계단, 집주변 도로, 출입문 주변환경, 집안 환경, 욕실 및 화장실, 부 억/주방의 하부영역, 총 70 문항의 낙상환경위험평가 도 구 초안을 만들었다.

3년 이상의 방문건강관리사업 경력을 가진 방문 간호 사 7 인과 간호학 전공 2 인의 실무자 자문회의를 통해 우리나라 노인의 거주 환경에 적절한 문항이 되도록 총 70 문항의 초안 문항에서 반복되거나 비슷한 내용을 제 외하는 등의 문항을 수정 보완하여 예비 낙상환경위험 평가 도구를 총 57 문항으로 구성하였다. 하부영역별로 는 집주변 계단 11 문항, 집주변 도로 5 문항, 출입문 주 변 환경 5 문항, 집안 환경 15 문항, 욕실 및 화장실 12 문 항, 부억/주방 9 문항이었다.

\subsection{2 내용타당도 검정}

예비문항으로 선정된 낙상환경위험평가 도구 총 57 문항에 대해 경력이 3 년 이상인 간호사 10 인과 관련 전 공 교수 10 인의 전문가를 대상으로 우리나라의 낙상환 경위험평가 문항으로 타당한지 내용타당도를 2 차에 걸 쳐 조사하였다. 각 문항의 타당도 정도는 '매우 타당하 다' 4점, '대체로 타당하다' 3점, '별로 타당하지 않다' 2 점, '전혀 타당하지 않다' 1점으로 하여 내용타당도 지 수(CVI, Content Validity Index)를 산출하였다. 내용타 당도 지수(CVI)가 $50.0 \%$ 이하이면 내용타당도가 없다 고 판단하고 $80.0 \%$ 이상이면 내용타당도가 높다고 판 단하기에[23] 80.0\% 이상 되는 문항만을 선정하였으며, 10 일 후 동일한 전문가에게 1 차 전문가 내용타당도 검 정 후 수정, 삭제된 54 문항에 대해 2차 전문가 내용타당 도 검정을 실시하여 역시 내용타당도 지수 $(\mathrm{CVI})$ 가 $80.0 \%$ 이상 되는 문항만을 선정하였다. 두 번의 전문가 자문회의 후 연구진과 실무전문가의 검토를 거쳐 최종 52 개 문항의 낙상환경위험평가 도구를 완성하였다.

\section{2 신뢰도 및 타당도 검정 단계 \\ 2.2 .1 연구대상}

대상자 수는 G-power 3.1 프로그램을 활용하여 산정 하였을 때, two-independent samples t-test로, 유의수 준 .05 , 보통 효과크기 $.30, .95$ 의 검정력을 위해 필요한 표본수는 각 집단별 136 명으로 총 272 명이었다. 본 연 구에서는 제주시 지역적 분포를 고려하여 재가노인 300 명을 대상으로 가정방문 관찰 및 면접조사를 실시하였 다. 구체적인 대상자 기준에는 만 65세 이상의 노인으 로 가정방문을 허락한 자로 설문응답이 불가능할 정도 로 인지기능이 낮은 노인의 경우는 제외하였다. 대상자 에게 자발적인 참여와 함께, 원한다면 연구 기간 중에 참여를 중단할 수 있음을 알리는 등 사전에 면접 지침 에 의거하여 조사자 교육을 실시하였고, 대상자의 익명 보장과 설문 결과는 본 연구만을 위해 사용될 것을 설 명한 후 서면동의를 받았다. 300 명의 조사 대상 가운데, 응답이 불성실한 1 부를 제외한 299명을 분석에 이용하 였다. 모든 자료수집은 $\mathrm{J}$ 대학교에서 IRB의 승인을 받 은 후 이루어졌다(IRB 승인번호 2012-16).

\subsection{2 조사자간 신뢰도 조사}

내용타당도 조사를 거쳐 수정 보완된 52 개 문항의 낙 상환경위험평가 도구를 이용하여 실태조사에 참여할 경력 3년 이상의 방문간호사 5 인과 조사자간 신뢰도를 파악하기 위해 조사에 참여할 간호사 1 인을 대상으로 교육훈련을 실시하였다. 각 문항의 응답 기준을 마련하 였고, 조사자간 일관성을 유지하도록 돕기 위해 조사 지침서를 만들어 배포하였다. 또한 교육훈련을 통해 그 의미가 명확하지 않은 문항은 일부 수정 보완하였다.

교육효과를 확인하기 위해 교육 후 대상자 관찰을 시 행 할 방문간호사와 연구간호사가 2 인 1조로 짝을 이루 어 새롭게 개발한 낙상환경위험평가 도구로 노인 대상 자 5 명의 가정을 방문하여 각자 그 위험도를 평가, 기록 하고 점수를 비교하였다. 이 때 두 명의 관찰자 간 낙상 환경위험평가 점수가 전혀 차이가 나지 않을 때까지 훈 련하였다.

매 방문시 해당지역 방문간호사 1 인과 연구간호사 1 인이 짝이 되어 총 63 가구를 함께 방문하여 조사하였으 
며, 조사 후 문항별 응답의 일치도를 확인하고자 하였 다. 조사자간 신뢰도 조사는 9월 10일부터 9월 28일까 지 실시하였다.

\section{2 .3 조사-재조사 신뢰도}

낙상환경위험평가 도구는 각 하부영역별 상황을 파 악하는 문항으로 구성되어 있어 조사-재조사 신뢰도를 측정하였다. 조사-재조사 신뢰도를 측정하기 위해 조사 대상자 중 1차 조사 후 특별히 환경이 변하지 않은 대 상 51 명을 임의 선정하여 조사 시점에서 1 개월 이내에 재방문하여 낙상환경위험평가를 다시 실시하여 응답의 일치율을 산출하였다.

\subsection{4 자료수집}

자료수집은 본 연구의 목적과 내용 및 주의사항에 대 해 교육을 받은 조사자가 가구방문을 하였으며, 대상자 에 따라서 직접 기재하거나, 질문지를 읽어주고 응답하 거나 직접 관찰 등 일대일 면접을 통해 수집하였다. 조 사기간은 조사자간 신뢰도 조사를 위해 9월 10일부터 9 월 28 일까지 조사하였고, 본 조사는 10월 10 일까지 실 시하였고, 조사-재조사 신뢰도 측정은 10 월 26일까지 재방문하여 조사하였다.

\section{3 자료분석}

수집된 자료는 연구 목적에 따라 SPSS window version 18.0 프로그램을 이용하여 분석한다.

1) 대상자의 일반적인 특성, 낙상관련 특성은 빈도, 백분율, 평균과 표준편차를 이용하였다.

2) 예비도구의 내용타당성 검증은 내용타당도 지수 (CVI, Content Validity Index)를 산출하였다.

3) 낙상환경위험평가 도구의 조사자간 신뢰도 검증 은 Cohen's kappa coefficient를 이용한다.

4) 낙상환경위험평가 도구의 신뢰도는 조사-재조사 방법을 통하여 일치율을 산출하였다.

5) 낙상환경위험평가 도구의 구성타당도를 검증하기 위하여 최근 6 개월 이내 낙상 유무에 따른 집단비 교법(t-test)을 실시하였다.

\section{III. 연구 결과}

\section{1. 예비도구의 내용타당도 검정}

1 차 전문가 내용타당도 조사에서는 문항별로 내용타 당도 지수(CVI)와 자문의견에 근거하여 일부 내용을 수정하였다. 또한 의미상 반복되거나 합쳐질 수 있는 항목도 수정하였다.

하부영역별로 '집주변 계단'에서는 내용타당도 지수 가 모두 $80.0 \%$ 이상 되었으나 2문항을 다른 문항과 합 쳐도 될 것으로 판단되어 11 문항에서 9 문항으로 수정 하였다.

구체적으로 '계단의 난간이 설치되어있습니까?'와 '계 단의 난간이 흔들리거나 부서진 부분이 있습니까'가 합 쳐져 '계단의 난간이 설치되어 있지 않거나 흔들리거나 부서진 부분이 있습니까'로 수정되었고, '계단이 너무 가파릅니까'와 '계단의 한 단의 높이가 너무 높습니까' 가 합쳐져 '계단의 한단의 높이가 너무 높거나 가파릅 니까'로 수정되었다.

‘집주변 도로'에서는 ‘집 앞 길이 좁습니까?' 문항이 내용타당도 지수가 $70.0 \%$ 로 나타나 삭제하였으며, '집 앞길의 경사'에 대한 질문의 필요성이 언급되어 연구진 의 논의 후 '집 주변에 경사가 심해 내려갈 때 위험한 길이 있습니까'의 한 문항이 추가되어 최종 5 문항이 되 었다. 또한 집주변 도로의 범위를 언급해주는 것이 필 요하다는 의견을 반영하여 '집 밖 외부에 설치된 분리 수거나 음식쓰레기를 버리는 곳까지 정도의 범위로 한 정하여 판단'이라는 설명을 추가하였다.

'대문 주변'에서는 내용타당도 지수가 모두 $80.0 \%$ 이 상이었고, 역시 대문 주변에 대한 범위가 필요하다는 지적에 따라 대문에서 집으로 들어가는 길, 마당을 포 함하며, 아파트 출입구의 경우는 아파트 동(건물)에 들 어가는 곳에서 본인 호까지 가는 환경을 포함하도록 하 였다.

'집안(방, 거실)'에서는 내용타당도 지수가 모두 $80.0 \%$ 이상이었고 일부 문장에서 질문의 의도가 명확 하지 않은 것들을 수정하였고 최종 문항은 그대로 15 문 항이었다. 수정된 문항을 살펴보면 다음과 같다. '조명 스위치의 접근이 쉬운 곳에 있습니까'를 '집안에 들어왔 
을 때 전등스위치를 바로 켜기에 어려운 곳에 있습니 까'로 수정하였고, '집안의 조명이 너무 희미합니까'를 '집안에서 글을 읽기 어려울 정도로 조명이 어둡습니까' 로 수정하였고, '요나 돗자리, 카페트, 발매트가 잘 고정 되어 있습니까'를 '요나 돗자리, 카페트, 발매트가 얇아 서 걸어다닐 때 잘 밀립니까’로 수정하였다.

'욕실, 화장실'에서는 '화장실 문 내부와 외부에서 모 두 열 수 있게 잠금 장치가 되어 있습니까?' 문항이 내 용타당도 지수가 $75.0 \%$ 로 나타나 삭제하였으며, 그 외 문항은 일부 문항을 수정하였으며 최종 11 문항이 되었 다. 수정된 문항을 살펴보면, '바닥에 물이 있습니까'를 '바닥에 물이 자주 있는 편입니까'로, '샤워할 때 서 있 기가 어렵습니까'를 '샤워할 때 서 있기가 어려울 정도 로 천장이 낮거나 좁습니까'로, '변기에 앉고 일어서기 힘듭니까'를 '재래식 변기를 사용합니까'로 수정하였다. '부억/주방'에서는 내용타당도 지수가 모두 $80.0 \%$ 이 상이었고 일부 문장을 수정하였고 최종 문항은 그대로 9 문항이었다. 수정된 문항을 살펴보면, '전등스위치는 이 용하기 편리합니까'를 '전등스위치는 이용하기 불편합니 까'로, '사용하는 발받침대가 불완전합니까'를 '사용하는 발받침대가 고정되어 있지 않습니까'로 수정하였다.

2 차 전문가 내용타당도 조사에서는 54 개 모든 문항에 서 내용타당도 지수가 $80.0 \%$ 이상되었으나, '욕실, 화장 실'의 하부영역에서 ‘화장실, 욕실, 욕조의 바닥 또는 욕 실용 슬리퍼 또는 발판이 미끄럽습니까?'로 각각 질문 했던 문항을 합쳐 수정하여 최종 11 문항에서 9 문항으 로 수정되었다.

그 외 일부 문항에서 의미를 분명하게 하기 위해 수 정하였는데, 그 내용은 다음과 같다. 집안의 영역에서 '집안에서 글을 읽기 어려울 정도로 조명이 어둡습니까' 를 '집안의 조명이 생활하기 불편할 정도로 어둡습니까' 로, ‘욕실, 화장실'에서는 '바닥에 물이 자주 있는 편입 니까'를 '바닥이 대부분 젖어 있는 상태입니까'로, '샤워 할 때 서 있기가 어려울 정도로 천장이 낮거나 좁습니 까'를 '샤워할 때 서 있기가 어려울 정도로 좁거나 천장 이 낮습니까'로, '부억/주방'에서는 '전등스위치는 이용 하기 불편합니까'를 '전등스위치를 바로 켜기에 어려운 곳에 있습니까'로, '높은 곳에 둔 물건들을 꺼내야 하는
일이 자주 있습니까'를 '높은 곳에 둔 물건들을 꺼내야 하는 일이 매일 있습니까'로 '사용하는 발 받침대가 고 정되어 있지 않습니까'를 '사용하는 발 받침대가 안전하 게 지지되지 않습니까'로 '식탁의자가 안전하지 않습니 까'를 '식탁의자가 약하거나 안전하지 않습니까'로 수정 하였다.

최종 선정된 하부영역별 문항은 집주변 계단 9 문항, 집주변 도로 5 문항, 대문 주변 5 문항, 집안 15 문항, 욕실 및 화장실 9 문항, 부억/주방 9 문항으로 최종 52 문항이 었다[표 1].

\section{표 1. 예비 낙상환경위험평가도구 내용타당도}

\begin{tabular}{|c|c|c|c|}
\hline 하부영역 & $\begin{array}{c}\text { 1차 내용타당도 } \\
\text { 지수(문항수) }\end{array}$ & $\begin{array}{c}\text { 2차 내용타당도 } \\
\text { 지수(문항수) }\end{array}$ & $\begin{array}{c}\text { 최종 } \\
\text { 문항수 }\end{array}$ \\
\hline 집주변계단 & $85-100(11)$ & $90-100(9)$ & 9 \\
\hline 집주변도로 & $70-100(5)$ & $90-100(9)$ & 5 \\
\hline 대문주변 & $85-100(5)$ & $90-100(5)$ & 5 \\
\hline 집안(방, 거실) & $85-100(15)$ & $85-100(15)$ & 15 \\
\hline 욕실, 화장실 & $75-100(12)$ & $85-100(11)$ & 9 \\
\hline 부억/주방 & $90-100(9)$ & $80-100(9)$ & 9 \\
\hline 총문항수 & 57 & 54 & 52 \\
\hline
\end{tabular}

\section{2. 최종도구의 타당도 및 신뢰도 검정}

\section{1 대상자의 일반적 특성}

성별은 여성이 $72.2 \%$ 를 차지하였으며, 연령은 75-84 세 연령이 $50.2 \%$ 로 가장 많았다. 가구형태는 단독주택 이 $80.8 \%$ 로 대부분을 차지하고, 아파트는 $10.8 \%$ 에 불 과하였다. 독거인 대상자가 $57.5 \%$ 로 절반을 넘었으며, 2 명이 함께 사는 경우가 $31.4 \%$ 이었다. 의료급여 대상자 가 $49.9 \%$ 로 절반 가까이 되었으며, 경제수준에 대해서 는 매우 못 사는 편 또는 못 사는 편이라고 응답한 대상 자가 $64.0 \%$ 를 차지하였다[표 2].

\section{2 조사자간 신뢰도 검정}

조사자간 신뢰도를 검정하기 위해 대상자의 낙상환 경위험평가 시 간호사 2 명씩 짝을 이루어 측정한 후 조 사자간 낙상환경위험 평가점수가 일치하는지를 Cohen's kappa coefficient를 통해 분석한 결과는 [표 3] 과 같다. 
본 연구결과 조사자간 낙상환경위험 평가점수는 '주 로 사용하는 전화기가 방 밖에 있습니까' 항목의 kappa 값이 0.74로 나타났고, 나머지 51개 항목은 모두 kappa 값이 0.80 이상으로 나타나 조사자간 낙상환경위험 평 가점수는 매우 높은 상관관계를 나타내어 신뢰도가 인 정되었다.

\section{표 2. 대상자의 일반적 특성}

\begin{tabular}{|c|c|c|}
\hline 특성 & 범주 & $n(\%)$ \\
\hline \multirow{2}{*}{ 성별 } & 남자 & $83(27.8)$ \\
\hline & 여자 & $216(72.2)$ \\
\hline \multirow{3}{*}{ 연령 } & $65-74$ & $108(36.1)$ \\
\hline & $75-84$ & $150(50.2)$ \\
\hline & 85세 이상 & $40(13.4)$ \\
\hline \multirow{3}{*}{ 가구형태 } & 단독주택 & $240(80.8)$ \\
\hline & 아파트 & $32(10.8)$ \\
\hline & 다세대, 연립주택 & 25( 8.4) \\
\hline \multirow{3}{*}{ 가구원수 } & 1명 & 172(57.5) \\
\hline & 2명 & $94(31.4)$ \\
\hline & 3명이상 & $33(11.0)$ \\
\hline \multirow{2}{*}{ 의료보험 } & 건강보험 & $148(51.0)$ \\
\hline & 의료급여 & $142(49.0)$ \\
\hline \multirow{4}{*}{ 경제수준 } & 매우 못사는 편 & $77(26.2)$ \\
\hline & 못사는 편 & 113(37.8) \\
\hline & 보통 & $87(29.1)$ \\
\hline & 잘사는 편 & $17(5.7)$ \\
\hline
\end{tabular}

표 3. 낙상환경위험평가도구 조사자간 신뢰도

\begin{tabular}{|c|c|}
\hline 하부영역 & Cohen's kappa coefficient \\
\hline 집주변계단 & 1 \\
\hline 집주변도로 & $.88-1$ \\
\hline 대문주변 & $.95-1$ \\
\hline 집안(방, 거실) & $.74-1$ \\
\hline 욕실, 화장실 & $.94-1$ \\
\hline 부억/주방 & 1 \\
\hline
\end{tabular}

\section{3 조사-재조사방법을 통한 일치율}

낙상환경위험평가도구는 각 하부영역별 상황을 파악 하는 문항으로 구성되어 있어 신뢰도를 재조사방법을 통하여 측정하였다. 이를 위해 1 차 조사 후 특별히 환경 이 변하지 않은 대상을 1 개월 이내에 다시 재방문하여
측정하였다.

낙상환경위험평가 도구의 재측정 신뢰도는 하부영역 별로 살펴보면, 계단의 9문항에서 일치율을 88.2-100.0\% 의 범위로 나타나 비교적 안정되었다. 도로환경 5 문항 에서는 64.7-94.1\%의 범위로 나타났으며, '집 주변 길 바닥이 깨져있거나 울퉁불퉁한 부분이 있습니까?'는 $64.7 \%$ 로, '집 주변 길이 어두컴컴한 부분이 있습니까?' 도 $72.5 \%$ 로 일치율이 낮게 나타났다. 대문주변 5 문항의 경우도 일치율이 74.5-92.2\%의 범위로 나타났는데, 응 답율이 낮은 문항으로 '대문(아파트 출입 현관) 주변이 미끄럽습니까?' $74.5 \%$, '대문(아파트 출입 현관)에 문턱 이 있습니까?' $78.4 \%$ 로 나타났다. 집안의 15 문항에서는 70.6-96.1\%의 범위로 나타났으며, '집안에 들어왔을 때 전등스위치를 바로 켜기에 어려운 곳에 있습니까?'의 항목이 $72.5 \%$ 로 낮게 나타났다. 또한 '집안을 다닐 때 양말, 덧버선, 슬리퍼를 신고 다닙니까?'도 $70.6 \%$ 로 나 타났다. 옥실의 9문항에서는 80.4-96.1\%의 일치율로 나 타났고, 주방 9문항에서는 68.6-100.0\%의 범위로 나타 났으며, '높은 선반에 있는 물건을 꺼내기 위해 의자나 발판을 사용합니까?'의 항목이 $68.6 \%$ 로 낮게 나타났다 [표 4]. 전체적으로 52 개 문항에서 45 문항의 일치율이 $80.0 \%$ 이상되었다.

\section{표 4. 낙상환경위험평가도구 조사-재조사 신뢰도}

\begin{tabular}{|c|c|c|}
\hline 하부영역 & 일치율(\%) & 일치율이 낮게 나타난 문항 \\
\hline 집주변계단 & $88.2-100.0$ & \\
\hline 집주변도로 & $64.7-94.1$ & $\begin{array}{l}\text { - 집 주변 길 바닥이 깨져있거나 울퉁불퉁 } \\
\text { 한 부분이 있습니까?(64.7\%) } \\
\text { - 집 주변 길이 어두컴컴한 부분이 있습니 } \\
\text { 까?(72.5\%) }\end{array}$ \\
\hline 대문주변 & $74.5-92.2$ & $\begin{array}{l}\text { - 대문(아파트 출입 현관) 주변이 미끄럽 } \\
\text { 습니까?(74.5\%) } \\
\text { - 대문(아파트 출입 현관)에 문턱이 있습 } \\
\text { 니까?(78.4\%) }\end{array}$ \\
\hline $\begin{array}{l}\text { 집안 } \\
\text { (방, 거실) }\end{array}$ & $70.6-96.1$ & $\begin{array}{l}\text { - 집안에 들어왔을 때 전등스위치를 바로 } \\
\text { 켜기에 어려운 곳에 있습니까? (72.5\%) } \\
\text { - 집안을 다닐 때 양말, 덧버선, 슬리퍼를 } \\
\text { 신고 다닙니까? }(70.6 \%)\end{array}$ \\
\hline $\begin{array}{l}\text { 욕실, } \\
\text { 화장실 }\end{array}$ & $80.4-96.1$ & \\
\hline 부억/주방 & $68.6-100.0$ & $\begin{array}{l}\text { - 높은 선반에 있는 물건을 꺼내기 위해 } \\
\text { 의자나 발판을 사용합니까? }(68.6 \%)\end{array}$ \\
\hline
\end{tabular}




\section{4 구성타당도 검정}

구성타당도를 검정하기 위하여 최근 6 개월 이내 낙상 유무에 따라 대상자를 낙상군과 비낙상군으로 나누어 낙상환경위험평가 점수를 비교하였고, 그 결과는 [표 5] 와 같다. 즉 낙상군과 비낙상군의 낙상환경위험평가 점 수가 통계적으로 유의한 차이가 있었고( $\mathrm{t}=3.50, p=.001)$, 하부영역별로는 도로환경 $(\mathrm{t}=3.09, p=.002)$, 대문주변 $(\mathrm{t}=2.12, p=.035)$, 집안 $(\mathrm{t}=2.05, p=.041)$, 욕실 $(\mathrm{t}=2.40$, $p=.017)$ 이 통계적으로 유의한 차이가 있었다.

표 5. 낙상경험 유무에 따른 낙상환경위험평가점수 비교 $(\mathrm{N}=299)$

\begin{tabular}{|c|c|c|c|c|}
\hline \multirow{2}{*}{ 변수 } & \multicolumn{2}{|c|}{ 낙상경험 } & \multirow{2}{*}{$t$} & \multirow{2}{*}{$p$} \\
\cline { 2 - 3 } & 있음 & 없음 & & \\
\hline 집주변계단 & $0.87 \pm 1.62$ & $0.59 \pm 1.17$ & 1.74 & .084 \\
\hline 집주변도로 & $1.62 \pm 1.14$ & $1.20 \pm 1.10$ & 3.09 & .002 \\
\hline 대문주변 & $1.77 \pm 1.09$ & $1.53 \pm 0.88$ & 2.12 & .035 \\
\hline 집안(방, 거실) & $3.44 \pm 1.81$ & $3.03 \pm 1.58$ & 2.05 & .041 \\
\hline 욕실, 화장실 & $3.41 \pm 2.03$ & $2.85 \pm 1.86$ & 2.40 & .017 \\
\hline 부억/주방 & $1.30 \pm 0.99$ & $1.24 \pm 1.06$ & 0.48 & .633 \\
\hline 전체 & $12.42 \pm 5.07$ & $10.43 \pm 3.74$ & 3.50 & .001 \\
\hline
\end{tabular}

\section{IV. 논의}

본 연구에서는 재가노인 낙상환경위험평가 도구를 개발하고, 신뢰도와 타당도를 검정하였다. 도구개발과 정에서는 국내외에서 사용된 낙상환경위험평가 도구와 관련된 문헌을 검토하였고, 관련 분야 전문가의 회의를 통해 예비문항을 구성하였으며, 2 차에 걸쳐 10 명의 방 문간호사와 10 명의 간호학 전공 교수를 대상으로 내용 타당도를 실시하였다.

예비문항의 하부영역 및 내용 개발시 참고했던 국내 외 낙상환경위험평가 도구는 다음과 같다. 김소남[1], 김종민[13], 박영혜[14] 등이 사용한 Tideiksaar[12] 도 구는 49문항으로 현관, 집안, 계단, 목욕탕 및 욕실, 침 실, 부억의 하부영역을 가지고 있었고, 김미정[17]이 사 용하고 유형준[16]이 소개한 The Merck Manual of Geriatrics의 도구는 21문항으로 집전체, 주방, 화장실, 계단으로 구성되어 있었고, 최경원과 이인숙[8], 장인순
과 김동준[19], 장인순과 김수미[20] 등이 사용한 Josephson 등[18]의 도구는 24문항으로 집전체, 주방, 화장실, 안방, 계단 및 복도, 실외로 구성되어 있었다. 그 외 $\mathrm{CDC}$ 의 노인 낙상예방을 위한 가정환경 체크리스 트에 포함된 낙상환경위험평가 17 문항으로, 바닥, 계단, 주방, 욕실, 침실의 하부영역으로 구성된 도구[22], Minnesota Safety Council[21]의 낙상예방 가정안전 체 크리스트 35문항으로 입구, 욕실, 주방, 침실, 거실, 계 단, 야외, 복도로 구성된 도구를 기초로 하여 총 70 문항 을 개발하였다. 1 차 실무자 자문회의를 통해 57 문항으 로 수정하였고, 하부영역별로는 집주변 계단 11 문항, 집 주변 도로 5 문항, 출입문 주변환경 5 문항, 집안 환경 15 문항, 욕실 및 화장실 12 문항, 부억/주방 9문항이었다.

Tideiksaar[12] 도구는 49문항이었지만 개발 시 참고 했던 다른 도구들이 17-35문항이었던 것에 비하면 본 연구의 문항수가 전체적으로 많을 수 있으나 낙상환경 위험 체크리스트로 항목별로 빠뜨리지 않고 점검하는 것이 더 중요하다고 사려되어 전체적으로 의미상 반복 되거나 합쳐질 수 있는 항목은 수정하였으며, 1,2 차에 서 내용타당도 지수(CVI)가 0.80 이상인 항목을 선정하 여 최종 52 문항으로 수정하였다. 최종도구에 포함된 모 든 문항은 전문가 집단에 의하여 내용타당도가 검정된 문항이라 할 수 있다.

신뢰도는 조사자간 낙상환경위험 평가점수가 일치하 는지를 Cohen's kappa coefficient를 통해 분석하였다. 일반적으로 관찰자간 신뢰도를 평가하기 위한 절대기 준은 없으나 측정자료의 신뢰도가 받아들여지기 위해 서는 Kappa, ICC값이 0.80 이상이거나 일치율이 $80 \%$ 이상이어야 한다[24]. 연구 결과 '주로 사용하는 전화기 가 방 밖에 있습니까' 문항의 kappa 값이 0.74로 나타났 고, 나머지 51 개 문항은 모두 kappa 값이 0.80 이상으로 나타나 조사자간 매우 높은 상관관계를 나타내었다. 전 화기 문항에 낮은 신뢰도가 나온 것은 대상자가 핸드폰 을 주로 사용하지만 거실에 전화기가 있는 것을 조사자 간 각각 다르게 평가한 경우가 있었다는 것을 확인하였 다. 따라서 핸드폰을 주로 사용하는 경우는 전화기가 방 밖에 있더라도 위험요인이 아닌 경우로 파악해야 할 것이다.또한 방밖이라는 표현보다는 대상자가 '주로 거 
주하는 곳에 전화기가 설치되어 있습니까'로 문항을 수 정하는 것이 좀 더 정확한 응답을 얻을 수 있을 것으로 고려된다.

선행연구에서 환경적 위험요인 도구의 신뢰도에 대 해서는 특별한 언급없이 사용되는 경우도 있었고 [13][14][19][20], The Merck Manual of Geriatrics의 도 구를 사용한 김미정[17]은 Cronbach's a값으로 .74를, Tideiksaar[12]도구를 사용한 김소남[1]도 Cronbach's $\mathrm{a}$ 값 .73로, Josephson 등[18]의 도구를 기초로 한 최경 원과 이인숙[8]은 환경적 위험요인 도구를 집 내부 위 험요인과 집 외부 위험요인으로 구분하여 신뢰도를 Cronbach's a값 .63, .62로 제시하였다. 본 연구자는 낙 상환경위험평가 도구가 각 하부영역별 상황을 파악하 는 문항으로 구성되어 있다고 판단되어 도구의 신뢰도 를 재조사방법으로 측정하였다. 재측정 신뢰도를 일치 율 $80.0 \%$ 이상을 기준으로 할 때[24] 몇몇 문항에서는 일부 표현의 수정이나 분명한 기준이 필요한 것으로 나 타났다. 하부영역별로 살펴보면, 계단, 욕실의 경우 모 든 문항에서 $80.0 \%$ 이상의 일치율을 나타내 비교적 안 정되었다. 다른 영역에서는 일부 문항이 낮은 일치율을 나타낸 경우도 있었는데, 도로환경에서는 '집 주변 길 바닥이 깨져있거나 울퉁불퉁한 부분이 있습니까?'의 항 목이 $64.7 \%$ 이었는데, 이는 일부 대상자 가구 주변에서 도로공사를 하는 경우가 포함되었던 것으로 나타났다. 재측정 대상자 선정시 좀 더 명확한 기준과 주의가 요 구된다고 볼 수 있다. '집 주변 길이 어두컴컴한 부분이 있습니까?'도 $72.5 \%$ 로 나타났는데, 이는 겨울이 시작되 며 초기 조사 때 보다 빨리 어두워진 계절적 변화와 기 대수준의 변화에 따른 응답율의 차이를 고려할 수 있었 다. 대문주변에서도 '대문(아파트 출입 현관) 주변이 미 끄럽습니까?' $74.5 \%$, ‘대문(아파트 출입 현관)에 문턱이 있습니까?' $78.4 \%$ 로 나타났는데, 이는 조사자가 한달 내 재평가할 때는 좀 더 관찰에 훈련이 되어 주의 깊게 관찰을 하거나 대상자도 이전 보다 민감하게 반응하는 경우가 생기며 일치율이 낮아진 경우도 있는 것으로 사 려되었다. 집안의 영역에서는 '집안에 들어왔을 때 전등 스위치를 바로 켜기에 어려운 곳에 있습니까?' $72.5 \%$ 로 나타났는데, 이는 어렵다는 기준이 상대적이며 생각이
바뀐 경우가 포함된 것으로 파악되어 '집안에 들어왔을 때 전등스위치를 바로 켤수 있는 곳에 없습니까?'로 문 항을 수정하는 것이 바람직할 것으로 고려되었다. '집안 을 다닐 때 양말, 덧버선, 슬리퍼를 신고 다닙니까?'도 $70.6 \%$ 로 나타났는데 이는 재조사를 한달 후에 하면서 겨울이라는 계절적 변화에 따라 이전에는 양말, 덧버선, 슬리퍼 등을 신지 않다가 재조사 당시에는 신는 경우가 생기며 나타난 차이로 해석되었다. 주방에서는 '높은 선 반에 있는 물건을 꺼내기 위해 의자나 발판을 사용합니 까?' 문항이 $68.6 \%$ 로 나타났는데 이런 행위는 자주 발 생하는 것이 아니기에 나타난 차이라고 생각된다.

구성타당도를 검증하기 위하여 최근 6개월 이내 낙상 유무에 따라 대상자를 낙상군과 비낙상군으로 나누어 낙상환경위험평가 점수를 비교하였을 때 통계적으로 유의한 차이가 있었고( $\mathrm{t}=3.50, p=.001)$, 하부영역별로는 도로환경 $(\mathrm{t}=3.09, p=.002)$, 대문주변 $(\mathrm{t}=2.12, p=.035)$, 집 안 $(\mathrm{t}=2.05, p=.041)$, 욕실 $(\mathrm{t}=2.40, p=.017)$ 이 통계적으로 유의한 차이가 있었다. 계단과 주방을 유의한 차이가 나타나지는 않았지만, 전체적으로 낙상군이 비낙상군 보다 낙상환경위험평가 점수가 통계적으로 유의하게 높아 구성타당도가 있는 것으로 나타났다. 그러나 일부 지역에 거주하는 재가노인을 편의추출한 연구이기에 대상자를 좀 더 확대한 반복연구가 필요하다.

본 연구에서 개발된 도구는 우리나라 가정의 특성을 고려하여 개발된 도구로 단독주택, 아파트, 연립 및 다 세대 가구 등에 모두 적용할 수 있고, 전체 문항이 52 개 로 적지 않은 수이지만 낙상환경위험 요인을 가능한 모 두 확인한다는 의미에서 조사자 및 대상자에게 교육적 효과를 기대할 수 있으며, 각 문항에 대해 '예', '아니오' 로 쉽게 응답함으로써 대략 소요시간은 10 분 이내로 나 타나 재가노인을 대상으로 방문하는 간호사들이 사용 하기에는 적절할 것으로 판단된다.

본 도구를 이용하여 재가노인의 낙상환경위험 요인 을 파악하고 그에 따른 환경개선을 위한 다양한 간호중 재를 계획하는 것이 효과적인 낙상예방 프로그램의 한 요소가 될 것이다.

그러나 본 연구는 $\mathrm{J}$ 시에 거주하는 재가노인을 편의추 출한 노인가구를 대상으로 수행되었으므로 대표성을 
갖기 어렵다. 따라서 한국의 재가노인을 대표할 수 있 는 대상으로 다시 본 도구의 신뢰도 및 타당도를 검정 하는 연구가 필요할 것이다. 또한 시설에 거주하는 노 인을 대상으로도 적용가능한지 본 도구의 신뢰도 및 타 당도를 검정하는 연구가 필요할 것이다.

\section{V. 결론 및 제언}

본 연구는 65 세 이상의 재가노인의 낙상환경위험평 가 도구를 개발하고, 신뢰도와 타당도를 검정하는 방법 론적 연구이다. 도구개발 과정은 관련문헌 고찰을 통해 총 70 문항의 예비문항 초안을 만든 후 관련 전문가 9 인 의 1 차 실무자 자문회의를 통해 57 문항으로 수정하였 다. 57 문항에 대해 20 인의 관련 전문가에 의한 2 차에 걸 쳐 내용타당도 검정을 실시하여 최종 52 문항을 선정하 였다. 최종도구의 타당도 및 신뢰도 검정을 위해 65세 이상 재가노인 299명에게 자료수집을 실시하여 분석하 였다. 그 결과 조사자간 신뢰도는 1 개 문항을 제외한 51 개 문항에서 모두 kappa 값이 0.80 이상으로 나타나 신 뢰도가 인정되었고, 재조사방법을 통하여 나타난 일치 율은 45개 문항에서 모두 $80.0 \%$ 이상으로, 나머지 7 개 문항은 64.7-78.4\% 정도로 나타났다. 낙상군이 비낙상 군보다 낙상환경위험평가 점수가 통계적으로 유의하게 높아 구성타당도가 확인되었다.

낙상의 위험요인을 미리 파악하고 관리한다면 낙상 을 예방할 수 있을 것이다. 특히 환경적 위험요인도 낙 상에 기여하는 정도가 크기에 본 도구를 이용하여 재가 노인의 낙상환경위험을 평가하고 적극적인 낙상예방 중재가 계획되어야 할 것이다. 또한 대상자에 따라 교 육적 접근과 환경개선을 위한 재정 및 시설지원, 보조 기구 대여 등과 같은 중재가 포함되어야 할 것이다.

본 연구를 통하여 다음과 같이 제언하고자 한다.

1) 본 연구에서 개발된 도구의 일반화를 위하여 도시 및 농촌에 거주하는 한국 재가노인을 대상으로 반 복연구가 필요하다.

2) 시설에 거주하는 노인을 대상으로도 적용가능한 지 본 도구의 신뢰도 및 타당도를 검정하는 연구
가 필하다.

3) 본 연구에서 개발된 도구의 기준(cut-off) 점수를 제시하는 추후연구를 시도하여 낙상위험군의 재 가노인을 선별하며 우선적 간호중재가 적용될 수 있도록 안내하는 것이 필요하다.

4) 본 도구를 이용하여 나타난 낙상환경위험 요인을 중재하는 다양한 프로그램 개발 및 중재효과 연구 가 필요하다.

\section{참 고 문 헌}

[1] 김소남, "다면적 낙상예방프로그램이 지역사회 거주 저소득층 노인의 신체·심리기능과 가정환경 위험요인에 미치는 효과”, 한국노년학, 제 32 권, 제2호, pp.377-395, 2012.

[2] L. Rubenstein and K. R. Josephson, "ls and their prevention in elderly people: What does the evidence show?," The Medical Clinics of North America, Vol.90, pp.807-824, 2006.

[3] World Health Organization, "Global Report on Falls Prevention in Older Age," Geneva: World Health Organization, 2007. Retrieved January 21, 2013, from http://www.who.int/ageing/ ublications/Falls_prevention7March.pdf

[4] 정경희, 오영희, 이윤경, 손창균, 박보미, 이수연, 이지현, 권중돈, 김수봉, 이소정, 이용식, 이윤환, 최성재, 김소영, 2011년도 노인실태조사, 보건복 지부·한국보건사회연구원, 2012.

[5] 임경춘, 전경자, 윤종률, “노인의 낙상공포 여부에 따른 건강상태, 신체기능상태 및 가정환경 위험 비교”, 한국노년학, 제29권, 제4호, pp.1577-1589, 2009.

[6] Panel on Prevention of Falls in Older Persons, American Geriatrics Society and British Geriatrics Society, "ummary of the Updated American Geriatrics Society/British Geriatrics Society clinical practice guideline for prevention 
of falls in older persons," Journal of the American Geriatrics Society, Vol.59, pp.148-157, 2010.

[7] M. E. Tinetti and C. Kumar, "The patient who falls 'It's always a trade-off'," The Journal of the American Medical Association, Vol.303, No3, pp.258-266, 2010.

[8] 최경원, 이인숙, "도시빈곤 노인의 낙상발생 위험 요인에 관한 연구”, 대한간호학회지, 제 40 권, 제 4 호, pp.589-598, 2010.

[9] 조경환, “낙상”, 가정의학회지, 제 18 권, 제 11 호, pp.1201-1204, 1997.

[10] S. Iwarsson, V. Horstmann, G. Carlsson, F. Oswal, and H. W. Wahl, "Person-environment fit predicts falls in older adults better than the consideration of environmental hazards only," Clinical Rehabilitation, Vol.23, pp.558-567, 2009.

[11] T. Nikolaus and M. Bach, "Preventing falls in community-dwelling frail older people using a home intervention team(HIT): Results from the randomized falls-HIT trial," Journal of the American Geriatrics Society, Vol.51, pp.300-305, 2003.

[12] R. Tideiksaar, Falling in old age its prevention and treatment(2nd ed), New York: Springer, 1997.

[13] 김종민, $P R E C E D E$ 모형을 적용한 노인낙상사 고 위험요인분석, 이화여자대학교 대학원, 박사학 위 논문, 2009.

[14] 박영혜, "지역사회 재가노인의 낙상 위험요인 사 정”, 노인간호학회지, 제6권, 제2호, pp.170-178, 2004.

[15] M. H. Beers, R. Berkow, and A. J. Fletcher, The merck manual of geriatrics, Whitehouse station, N. J., 1999.

[16] 유형준, 머크메뉴얼 노인병학, 한우리, 2003.

[17] 김미정, 재가노인의 낙상위험요인, 한양대학교 대학원, 석사학위 논문, 2011.
[18] K. R. Josephson, D. A. Fabacher, and L. Z. Rubenstein, "Home safety and fall prevention," Clinics in Geriatrics Medicine, Vol.7, No.4, pp.707-731, 1991.

[19] 장인순, 김동준, "일부 농촌지역 노인의 낙상위 험을 높이는 물리적 환경에 관한 조사연구”, 노인 간호학회지, 제4권, 제2호, pp.176-186, 2002.

[20] 장인순, 김수미, "일부지역 재가노인의 낙상위험 요인 조사연구”, 노인간호학회지, 제 8 권, 제 2 호, pp.107-116, 2006.

[21] Minnesota Safety Council, "Fall prevention home safety checklist : What you can do to prevent falls," Minnesota Safety Council, 2004. Retrieved January 21, 2013, from http:// www.minnesotasafetycouncil.org/seniorsafe/fall check.pdf

[22] National Center for Injury Prevention and Control, "Preventing falls: How to develop community-based fall prevention programs for older adults," Atlanta, GA: National Center for Injury and Control, 2008. Retrieved January 21, 2013, from http://ww w.cdc.gov/HomeandRecreation alSafety/images/CDC_Guide-a.pdf

[23] M. R. Lynn, "Determination and quantification of content validity," Nursing Research, Vol.35, pp.382-385, 1986.

[24] J. C. Nunnally, and I. H. Bernstein, Psychometric theory (3rd Ed.), New York: McGraw-Hill, 1994. 


\section{저 자 소 개}

박 은 옥(Eunok Park)

정회원

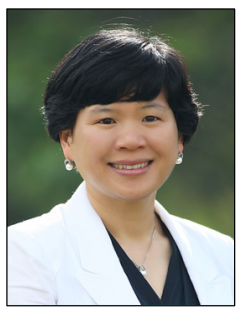

- 1991년 2월 : 서울대학교 간호학 과(간호학학사)

- 1994년 8월 : 서울대학교 보건대 학원(보건학석사)

- 1999년 2월 : 서울대대학교 보건 대학원(보건학 박사)

- 2000년 3월 현재 : 제주대학교 간호학과 교수

<관심분야> : 지역사회간호, 지역사회건강증진, 노인, 여성, 정신건강, 보건교육, 학교보건, 산업간호

장 인 순(Insun Jang)

정회원

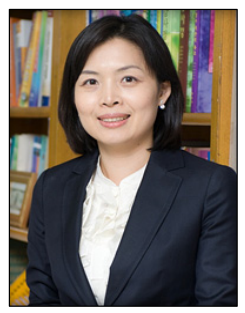

- 1990년 2월 : 서울대학교 간호 학과(간호학 학사)

- 1995년 2월 : 서울대학교 보건 대학원(보건학 석사)

- 2002년 2월 : 중앙대학교 간호 학과(간호학 박사)

- 2010년 3월 현재 : 한국성서대학교 간호학부 조교수 <관심분야> : 지역사회간호, 보건교육, 노인, 여성 